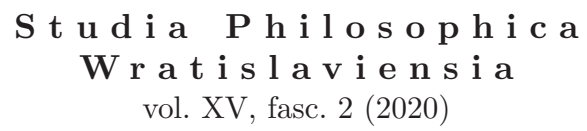

https://doi.org/10.19195/1895-8001.15.2.8

ISSAM KHIRALLAH

ORCID: 0000-0001-7914-9761

University of Wrocław

\title{
The Sufi Ethics of Annihilation and Responsibility in Al-Jabri's Critique of the Arabic Ethical Mind
}

\begin{abstract}
The paper outlines the interpretation of Sufism formulated by Mohamed Abed Al-Jabri, a contemporary Moroccan philosopher and critic of the Arabic tradition. According to him, Sufism, unknown to Arabic culture until the advent of Islam, originated through a historical conspiracy whereby the Persians attempted to weaken their new Arabic colonisers. Sufism is viewed by him as an evasion and a detachment from life and its problems. It leads its adepts, through the mystical journey, to renounce material life. It plunges its adepts into a way of life where the annihilation of the self in God represents the central value. This annihilation of the self in deity is possible only through the blind obedience of the Seeker $(M u$ reed) to his Master (Sheikh). Therefore, Sufism can only thrive by using tyrannical means. It demands that its adepts, through following a predestined path chosen by God, lose their own volition and freedom in favour of their Master. Breaking the law at the end of the Seeker's mystical journey reflects, paradoxically, a spiritual accomplishment. Additionally, Sufi orders maintain a congenial relationship with political tyranny. Consequently, I argue, Sufism leads to a loss of human responsibility for oneself and other beings. I also claim that in a post-tyrannical Arabic society, where responsibility for oneself and one's community should be the central value, Sufi ethics are unable to play a role in the promotion of modern values. For this reason, it should be prevented from shaping the political and social choices of a modern society and constrained to the mystical realm.
\end{abstract}

Keywords: responsibility, Sufism, freedom, annihilation of the self, obedience, tyranny 


\section{Introduction}

In his History of Islamic Philosophy, Henry Corbin provides a succinct account of mysticism in Islam known as Sufism:

As evidence of mystical religion in Islam, Sufism is a spiritual phenomenon of tremendous importance. Essentially, it is the realization of the Prophet's spiritual message, the attempt to live the modalities of this message in a personal way through the interiorization of the content of the Quranic Revelation. The mi'raj or "ecstatic assumption", during which the Prophet was initiated into the divine secrets, remains the prototype of the experience which each Sufi in turn attempts to recapture for himself. Sufism is a resounding affirmation, an irremissible testimony on the part of spiritual Islam against any tendency to reduce Islam to a legalistic and literalist religion. It was induced to develop a detailed technique of spiritual ascesis, whose stages, progress and aims require the existence of an entire metaphysical system which goes by the name of 'irfan. The polarity of shari'ah and haqiqah — or, to put it more fully, the triad formed by the shari'ah (the literal fact of the Revelation), the tariqah (the mystical way), and the haqiqah (spiritual truth as personal realization) - is thus essential to its life and doctrine. ${ }^{1}$

Sufism faces many difficulties when confronted with mainstream Sunni doctrine. To depart from the literalist interpretation of the laws of Shari'a, Sufism sunk in a new kind of extremism of the interpretation of the scripture, leading to a new meaning of human life. Its extremism lies in the fact that Sufism became an esoteric branch of Islam par excellence. Within it, most of the law loses its significance and is replaced by new values. These new values are linked neither to the reality and basic needs of the human being nor to the fundamentals of the Islamic creed. In fact, Sufism preaches resignation, social isolation and the lack of interest in life. It plunges into a non-natural code of conduct aiming at pure and high spirituality that washes out any meaning or raison d'être of material life.

The Sufi movements in the Arab-Islamic world play a tremendously significant role in shaping the lives of large sections of Arabic society. This poses a big challenge of bringing together the adepts of Sufism to accept and espouse common modern values with regards to freedom and responsibility. One of the reasons is Sufism's ideology which divides society into two major spiritual bodies: the ignorant who follow the literalist conception of religion, and those who acquired the truth through the mystical way. This hierarchy establishes inequality among citizens. In the following, I argue that Sufism has distorted the meanings of freedom and responsibility and therefore should be confined to the mystical sphere and not interfere in public or political matters.

\section{Al-Jabri's obedience paradigm}

In view of Al-Jabri's categorisation of the Arabic-Islamic tradition ${ }^{2}$ and the different influences it underwent since the codification era $^{3}$ (mainly through the Greek

\footnotetext{
${ }^{1}$ H. Corbin, History of Islamic Philosophy, transl. L. Sherrard, Ph. Sherrard, London 1962, p. 188.

${ }^{2}$ In his Critique of Arabic Mind, Al-Jabri claims that the Arabic-Islamic tradition is made of five distinct traditions: the Persian, the Sufi, the Greek, the Islamic, and the Arabic.

${ }^{3}$ Codification era refers to the period between the 8 th and to the 13 th century AD.
} 
and Persian traditions), one can acknowledge that Sufi ethics stand as the most controversial tradition with its positive and negative contribution to the shaping of the Arabic subject's self-awareness and worldview. Within Al-Jabri's radical stance towards Sufism, it is interpreted as the resignation of the Arabic subject, an expression of a tyrannical state of mind and even a conspiracy scheme in the hands of the weak and, paradoxically, of the powerful. Al-Jabri asserts: "Sufism could be described from a theoretical view as the resignation of the mind. It can also be described as a detachment from life and its problems (from a pragmatic perspective) which is a negative attitude towards life". ${ }^{4}$

In opposition to the ethics of life advocated by the scripture and the prophet of Islam, Sufism promotes a system of negative values. The Sufi value system focuses on the value of 'Fana' $e$ ', or annihilation of the self which constitutes its raison d'être. As a socio-religious phenomenon, it is a hierarchy organised around the Sheikh (or Master) and the Mureed (or Seeker). Al-Jabri is right when opposing the Suf "annihilation of the self" concept to the monotheistic idea of Islam. In fact, the annihilation of the self is the last stage (or station) of the Sufi subject's mystical journey through hardships, frustrations, and resignation. It leads the seeker (Mureed), or apprentice, to the unity with God, where he becomes a part of the deity. A reader can easily infer how this contradicts not only the very essence of the Islamic monotheistic message, which assumes a strict separation between the human being and the deity, but also the positive approach towards life that Islam pleads for. And yet, Al-Jabri demonstrates how the Sufi schools and ethics managed to thrive in the Islamic society, and he claims that it was, in the beginning at least, a part of a conspiracy of the Weak. ${ }^{5} \mathrm{He}$ also claims that Sufism originated and thrived in Persia, a land colonised by Arabs after the advent of Islam, as a response to the dominance of the Arabic civilisation over the Persian one. It was the premeditated response that the colonised (the weak) infiltrated in the young Arabic Islamic society in order to weaken it from within. It is no surprise that till now Sufism favours isolating oneself from life and its material benefits, resigning from the struggles and needs of life, and seeks the annihilation of the self through identification with a supra-existent deity. The Persians infiltrated and spread these new ideas among the Islamic society, sowing seeds of doubt in the Muslims' minds. Al-Jabri argues that this is a conspiracy. His proof is that the Arabic community did not know Sufism and that it was an importation from the Persians. He claims that by introducing this new value system among the Muslim youth in the name of Islam, the Persians wished to weaken the empire by destroying the Muslim Self and Mind. It was a sort of a cunning resistance to the new Arabic Power. "Sufism was using Islam to breach the unity of religion and thus weaken the state (it started in Kufah and Basrah during the Omayyad dynasty). The battle was ideological, but also very pragmatic. A Sufi youth doesn't marry or has children, doesn't go to war, doesn't work and is a charge on the society". ${ }^{6}$

\footnotetext{
${ }^{4}$ M.A. Al-Jabri, The critique of Arab Mind: the Arabic Ethical Mind, Beirut 2001, p. 429.

${ }^{5}$ Ibid.

${ }^{6}$ Ibid., p. 430.
} 
He also stressed the fact that negative attitudes towards life generally occur during the demise of civilisations and not in the period of their flourishing, ${ }^{7}$ while in the case of Arabic societies they appeared at the beginning of the Arabic civilisation. To answer this paradox, Al-Jabri introduces an internal factor intrinsic to the new Arabic-Islamic society: the crisis of values that stemmed from Fitna (the political wars following the death of the Prophet). The crisis had prepared a fertile ground for the thriving of Sufism, especially among those who isolated themselves from the internal political disputes that led to ravaging wars. The intrinsic crisis was conducive to the importation of new ideas. A large section of society, having found no way out from the ethical crisis, decided to isolate themselves from the political disputes by choosing the way of Sufism. ${ }^{8}$

Al-Jabri explains that in order to achieve the annihilation of the self through identification with the deity, Sufism followed the trail of obedience and tyranny. In fact, Sufism is promoted through orders or lodges. The order is organised around a Master (Sheikh) and apprentices or Seekers (Mureed). The Seeker gives up his freedom and responsibility and places himself in the hands of the Master. He becomes blindly obedient to the Master's will and commandments. Obedience becomes his sole responsibility in life. During his spiritual journey, the Mureed crosses seven stages or Maqams ${ }^{9}$ before attaining the highest spiritual rank of the unity with the deity. These seven spiritual stages embody the resignation from life and its material aspect. The journey almost suppresses any conception of the material aspect of human life. Kubilay Akman claims that: "For Sufi practices liberating oneself from material desires take an important role. [...] Sufism is the name of freedom, abstaining from artificiality, having generosity and the spending of wealth. A Sufi should not be selfish in worldly actions and be free from desire and greed. Generosity in the world means that worldly goods should be given to worldly people. ${ }^{10} \mathrm{Ku}-$ bilay cites also Junayd Baghdadi, ${ }^{11}$ one of the early Sufi Masters, who claimed that "Sufism is founded on eight qualities: Generosity (the Generosity of Prophet Abraham), Acceptance (the acceptance of Prophet Ishmael), Patience (the patience of Prophet Job), Signs (the signs of Prophet Zechariah), Poverty (the poverty of Prophet John), Woollen Robe (the woollen robe of Prophet Moses), Travelling (of the travelling of Prophet Jesus), Piety (the piety of Prophet Muhammad)". ${ }^{12}$

7 Ibid., p. 420.

8 Ibid., p. 430.

${ }^{9}$ Maqams are spiritual stations forming the stages of a journey of the mystic seeker: Tawba (Repentence), Wara' (Watchfulness), Zuhd (Renunciation), Faqr (Poverty), Șabr (Patience), Tawakkul (Trust and reliance on God), and Riḍa (Acceptance). In other sources there are only six stations that can be referred to as, firstly, the stage or Maqam of ego (Nafs), secondly, the stage of heart (Qalb), thirdly, the stage of the soul (Ar-ruh), fourthly the stage of the divine secrets (As-sir), fifthly, the stage of nearness and sixthly (Qurb), the stage of union (Wisal).

10 A. Kubilay, "Sufism, Spirituality and Sustainability-Rethinking Islamic Mysticism through contemporary sociology", Comparative Islamic Studies 4 [1-2] (2008), p. 13, http://images.gmanews.tv/ pdf/aseanconf/AKMAN\%20Kubilay.pdf.

11 Or Junayd of Baghdad (835-910 AD).

12 A. Kubilay, "Sufism, Spirituality...", p. 14. 
Behind the Sufi ideas are stories about prophets that all emphasise one important feature: poverty and simplicity.

According to Sahl Et-Tostouri, a prominent Sufi figure of the ninth century, "the distinctive attributes of the mystic are three: becoming poor after having been rich, being humble after having been superb, being unnoticed after having been noticed". ${ }^{13}$ Abu Ali El-Asfahâni, a disciple of Sahl Et-Tostouri, speaking about the attributes a Sufi should have, stated the following: "The Sufi is the one that wears wool, possesses a pure heart, gives up the world disdainfully and follows the path of the Elected". ${ }^{14}$ Abu Otman Bekr ben Mohammed El-Basrî, another Sufi figure of ninth century Iraq states: "To be divested of riches, to purify one's soul of social hopes, to see the truth in everything around, these are the signs of the Sufi". ${ }^{15}$

Thus, the mystical and spiritual aspects of the Sufi subject are overwhelming, creating therefore a structural imbalance in the Sufi subject's experience with his public sphere. The main drive of the Mureed's mystical journey towards the highest maqam (stage) is fear. However, as Al-Jabri explains, it turns out that this fear is a catalyst towards tyranny. Immobilisation and resignation of the Sufi subject is achieved through fear which leads one to give up the administering of the future to the unknown. It uses Tawakkul (reliance on God) by getting away from work and from building and multiplying. It consecrates the full meaning of tyranny and loss of freedom by emphasising the role attributed to the Sheikh (Master). Al-Jabri's radicality goes even further when he claims that "The annihilation of the Self promoted by Sufism leads to (and is truly and foremost) an annihilation of the human ethics and thus to the annihilation of Humanity itself'. ${ }^{16}$ In elaborating on Ibn Arabi's ${ }^{17}$ concept of freedom, Muhammad Al-Masbahi left no doubt that freedom for Sufism is at the heart a question of spirituality that is reflected in servitude and obedience. "Freedom for Ibn Arabi is not pragmatic (ethical, political, social or cultural), it does not try to get rid of the tutorship of tyranny and social and cultural oppressions, it is not a rational freedom as it does not try to overcome the obstacles of nature. The absolute freedom is achieved through obedience and servitude to the deity". ${ }^{18}$ It becomes evident how Sufi orders claimed the use of obedience as a way to achieve freedom. The twist here is that such obedience is no longer pledged to God directly but rather through the spiritual guide (Sheikh). In this way, the Master takes precedence over God in the Seeker's spiritual journey. Al-Masbahi states further: "the horizon or ultimate goal of Ibn-Arabi's thought is not a human one. He does not aim through it to free humans from the shackles that limit one's manhood, energy, and creativity, it is a divine horizon whose ultimate goal is the guarantee of the absolute obedience and servitude to God and

${ }^{13}$ S.A. Ben Ridouane, Etude sur le Soufisme, Fenn at-Tassawwouf, transl. M.A. Arnaud, Whitefish 1888 (2010 Edition), p. 13.

14 Ibid.

15 Ibid., p. 23.

16 M.A. Al-Jabri, The critique of Arab Mind..., p. 475.

17 Arguably the most influential medieval Sufi reference who lived between 1165-1240 AD.

18 M. Al-Masbahi, "Freedom as servitude for In Arabi", Al Azmina Al Haditha: Philosophical Publication: The questions and stakes around Freedom 5 (2012), p. 37. 
a complete annihilation into him because he is the real Master and the only free Being". ${ }^{19}$ Nonetheless, Al-Masbahi does not lack arguments to demonstrate that Ibn-Arabi was the strongest defendant of freedom among Arabic philosophers and scholars of discourse (Kalam). ${ }^{20}$

The fact remains that freedom for Ibn Arabi was an exclusively spiritual concept, whose goal is the unity of being with God. This meaning given to freedom indicates the disinterest with which the Sufis approach the material life. It is a freedom with the ultimate purpose of servitude and obedience. Ibn Arabi claims that the more obedient one is to God, the freer one is on earth. This servitude is due to the spiritual Master who plays the role of an intermediary. Finally, the Master ends up taking the place of God, who is the embodiment of tyranny in the Sufi order.

After God, the Sheikh becomes the centre of thought and aspirations of dervishes (disciples). He is the most perfect and most complete manifestation of the divine, he is the shelter and the model of every novice, the beauty of his holiness is reflected in his mystical experiences. He is God's lieutenant, the mirror in which God is revealed; Whoever is associated with him becomes associated with God. Whoever sees him, sees God and whoever knows him, knows God. For the novice the hand of the Sheikh is the hand of God, his voice is that of God, his injunctions are those of God, his approval is that of God. ${ }^{21}$

Thus, Sufism sees freedom through a unity in the Being (God) and humanity's unique way of salvation is to follow the path of seeking obedience and servitude.

Therefore, responsibility in the eyes of Sufism is the absolute submission to the spiritual guide or Master. Carl-A. Keller cites a twelfth-century Sufi author, Abu Al-Najib Abd Al-Qahir Al-Suhawardi, who says "that the one who wakes up to the search of the God [referring to a seeker of truth or future disciple] must hurry and meet a competent Master in a total submissive attitude". ${ }^{22}$ Keller declares that "the association between the Master and his disciple (Mureed) resembles that of a contract: the disciple renounces his own will and submits himself to the injunctions of his Sheikh (Master), and this one undertakes upon himself to bring the disciple closer to God". ${ }^{23}$

\section{Mohamed Ahmed Qadri states:}

If a Sufi is really anxious to move towards his spiritual destination, he should follow the instructions of his spiritual guide and there should be no shadow of doubt about the commands of his Sheikh. Because the Sheikh is a focal point of spirituality. If someone has doubt about his Sheikh or feels that he can attain the stations [or stages] of Tassawuf (Sufism) without him, that would be a wrong imagination, a false behaviouristic approach because the entire basis of Sufism requires the Sheikh and his willingness [...] the Sheikh is a kind of permission to get further steps or advancement in Tassawwuf. ${ }^{24}$

\footnotetext{
19 Ibid., p. 38.

${ }^{20}$ Ibid., p. $39-40$.

${ }^{21}$ R. Gramlich, Die schiitischen Derwischorden Persiens. Zweiter Teil: Glaube und Lehre, Wiesbaden 1976, p. 182; cited in: C.-A. Keller, Une approche de la mystique dans les religions occidentales et orientales, Paris 1996, p. 91.

${ }^{22}$ C.-A. Keller, Une approche de la mystique..., p. 88.

${ }^{23}$ Ibid., p. 89.

${ }^{24}$ M.A. Qadri, What is Tasawwuf? An answer by Hadrat Ali bin Uthman al-Hajweri, IECRC online publication, 2003, p. 10, http://www.iecrcna.org/publications articles/Tasawwuf/_Data_Ganj_ Buksh.pdf.
} 


\section{Likewise, Sheikh Abdehadi Ben Ridouane informs us that:}

The Imam El-Cha'rânî asserts that "the Sufi scholars agree on the necessity for a seeker to follow a Master in order to attain the annihilation. Each human that has no guide to follow is guilty of rebellion towards God and his prophet, as he wouldn't reach salvation without a guide, even though he might have learnt 1000 theological books. The analogy is made with a person who has learnt medicine through books but has never put his knowledge into practice, so he would be unable to apply a remedy to the ache. Follow a private tutor my brother, hear my advice and hold back from saying that the Sufi path is not permitted by the Book or the Sunnah, as this would be an impiety. Sufism is entirely a Mohamedian endeavour. The warp and weft of the Sufi fabric are Mohamedian". ${ }^{25}$

The above citations are a clear invitation to the blind obedience to the spiritual guide; it reflects an attempt to contain any spiritual emancipation, it discourages free will within an established order, it is a decree by which the tyranny is established within contours not defined through reason or rationality. This is because freedom is, first and foremost, synonymous with obedience as seen earlier. It is also a freedom from the material life. Along his journey, the Sufi subject loses his free will to his Master. Through the mortification and decimation of his desires and needs, the Sufi subject reaches the stage of the annihilation of his self into the divine Being. He reaches the state of non-existence in which he feels he has no needs or desires. To achieve this, the Sufi subject is supposed to suppress his free will and not oppose anything within the order he belongs to. Responsibility translates into the detachment from life and freedom into servitude. Ibn'Ata Er-Raoudabari ${ }^{26}$ states: "The first step in the path of Sufism consists of being in the hands of the Truth such a passive body without any will in the hands of its Washer [referring to the one who washes the body after one dies]". ${ }^{27}$ Sheikh Abdehadi Ben Ridouane asserts that "for Sufis, the Seeker is the one who has stripped himself of his own will...it is the one whose heart is always busy with searching the Lord. The seeker becomes immersed in the ecstasy, loses his volition without pain or suffering. He crosses all limits of his own nature". ${ }^{28}$

To sum up, Sufism, according to Al-Jabri, leads to many human disasters: tyranny and full and blind obedience to the Master (Sheikh), a negative attitude towards life, the annihilation of human ethics, which the Sufis call the annihilation of the Self in God, the total loss of responsibility for oneself, other humans and all beings in general. "Sufi scholars (Abu Sulaiman darani ${ }^{29}$ as an example) claim that no choice has ever been given to humans as they are predestined to do all the deeds and later to enter whether to hell or heaven". ${ }^{30}$ They claim God had chosen those whom he is pleased with before he even created them, which eventually deprives them of free will. Consequently, whoever annihilates himself in God by loving him, does not have to observe ethical norms. The suppression of free will and belief in God's love are the sufficient grounds for the claim that Sufi deeds are no longer

\footnotetext{
25 S.A. Ben Ridouane, Etude sur le Soufisme..., p. 35.

${ }^{26}$ Full name Abu Abdallah Ahmed ben 'Ata Er-Raoudabari from Syria, died in 979 AD.

${ }^{27}$ Cited in S.A. Ben Ridouane' Etude sur le Soufisme..., p. 23.

28 Ibid., p. 36.

${ }^{29}$ A Sufi from the 8th-9th century.

${ }^{30}$ M.A. Al-Jabri, The critique of Arab Mind..., p. 480.
} 
to be assessed as good or bad. This denial of the law is the expression of absolute freedom that they attained through the annihilation of the self, the last of the three-stages process.

These three stages of freedom in Sufism can be depicted as follows: freedom of the self from desires and pleasures (this is taught first to the Mureed at the beginning of his mystical journey ), freedom that the Mureed enjoys when he reaches the last stage of the annihilation (elite freedom) and lastly, freedom of the elite of the elite. This last stage of freedom involves freeing oneself from any obligations or duties. The Mureed reaches the stage of unification with God and becomes free from any duties (he can do anything, engage in all desires and pleasures, lie, steal, cheat, etc.). They claim that the state they reach is, henceforth, that of the presence of God in them. They reach this stage by respecting all duties and by cleansing their selves. Now that their selves are purified, they reach freedom and truth and enjoy the presence of God while disregarding all duties God endowed them with in the first place.

Al-Jabri claims that

these ideas are not born within Islam. They are born in Hermeticism and embraced by the Persians who later transferred them to the Muslim society through Sufism. Ibn Arabi based his understanding of the Islamic text on Hermeticism. For him, the intrinsically good and bad does not exist. Evil people do evil because they follow their natural inclinations which lead them to do so. And so do the good people. It is predestination. Doing evil is a kind of obedience to the structural command of predestination but, at the same time, it is a disobedience to the duties and responsibilities. Since the structural command is set prior to the command of duties and responsibilities, there is in the end no real free will and thus no final judgement or punishment. Disobedience and obedience are just the same thing. ${ }^{31}$

First, "the Seeker must begin his mystical journey with a strong feeling of guilt and fear to end up later on with freeing himself from them and believing in no punishment in the afterlife. Responsibility is therefore weakened. The laws of Shari'a are denied and laws of Sufism are embraced and established". ${ }^{32}$ Despite all the negativity that Al-Jabri associates with Sufism, he excludes from his judgment the individual Sufi experience that does not aim at enslaving people or depriving them from their freedom or freeing them from the material life and its duties. In fact, there are numerous scholars or simple individuals that seek highly spiritual states and prolifically share their experiences without any intention to establish orders that adopt or enslave followers, etc. These experiences are strictly limited to their persons and do not depart far from the core message of Islam.

In Al-Jabri's view, the Sufi orders are a continuation of political tyranny as they themselves are built on the principle of blind obedience, the lack of freedom and the absence of responsibility and accountability. The political establishments in Arabic societies use these orders to create a docile population that does not speak for its rights, and does not hold the political representatives accountable for their actions. This can be achieved because, since their beginning, the Sufi orders have shown little or no opposition to political establishments, no matter how tyr-

\footnotetext{
31 Ibid., p. 485.

32 Ibid., p. 484.
} 
annical they may have been. This political disinterest is the logical consequence of the resignation from the economic and material life.

In fact, tyrannical states have always intervened in shaping the values of society by promoting some values over others through the instrumental use of religion and the teachings of mainstream Sunni scholars, as well as by financing the Sufi orders that reinforce the power of a privileged minority. It has become a common practice for the political establishment to use strategies of reprioritisation, suppression, overuse, and misinterpretation of the scripture's ethical values to promote the value of obedience among Arabic subjects. The political establishment's main purpose has always been to shape the Arabic subjects' worldview, their understanding of freedom and responsibility, their relationship to the political power, their duties and their rights. The crisis in the Arab-Islamic civilisation is specifically a politico-religious one. Using the fact that religion occupies a central role in the mindset of the community, the political sphere has made use of the religious sphere to subdue large sections of society. By accommodating and manipulating religious ethical values, the political establishment secures for itself a durable political and economic dominance.

\section{The social implications of the weak Sufi responsibility}

The conception of freedom that can be inferred from Sufism translates into a very specific definition of responsibility. Responsibility in Sufism is ultimately a form of evasion and renouncement. It is a desertion from life and its tangibility, it is an attempt at the containment and repression of human impulses, drives and worldly goals through self-discipline. It is a constant denial of one's own nature. It is a punishment for one's own desires, senses, and aspirations. Sufism sees the human worldly goals as harmful to its one and unique goal: the annihilation of the self in the godly Being. Life and its material riches are but a sort of temptation to which the self ought not to succumb. Sheikh Abdehadi Ben Ridouane states: "The Sufi must show continence or renunciation $(Z u h d)$. Continence is the action by which the desire is constrained. It is closing one's ears to the voice of passions [...], it is having open eyes but only for immaterial reality. El-Ghazâli defines continence as such: it is the escape from the world, even though one is powerful, whether for the sake of [the afterlife] or for the sake of diverting one's eyes from whatever is not Truth". ${ }^{33}$ He continues: "The continence or the ascetic poverty means not to possess goods of this world but [only] in small quantities, enough to ensure getting rid of one's hunger and covering one's nudity. Also, the habitation must be a simple shelter against the heat and cold and the furniture must come down to the most necessary things". ${ }^{34}$

This continence implies a certain degree of isolation from society which, as a matter of fact, leads to the shrinking of the scope of the Sufi ethical intervention and commitment. Even though the Sufi subject (disciple) could exercise excellent

\footnotetext{
${ }^{33}$ S.A. Ben Ridouane, Etude sur le Soufisme..., p. 25.

34 Ibid.
} 
ethical conduct during his mystical journey, his isolationism and renunciation from the material life makes it hard for him to exert and spread kindness and generosity among his peers. The Sufi adept chooses to desert the worldly life affairs: business, politics, militancy, science and arts etc., which makes him a marginal subject in his society.

We have seen that Sufism starts with continence and ends with the denial of the law. Once they reach that stage of their annihilation within the deity, the Sufis immerse themselves in all sorts of pleasures and desires. Both outcomes are tragic. The denial of the law, secular or religious, is synonymous with not holding oneself responsible for one's actions, whereas the renouncement of and detachment from life is a negative approach to life that is contrary to social responsibility.

For Carl-A. Keller, "the mystic" (including the Sufi) is a marginal subject, a lunatic who becomes useless to society". ${ }^{36}$ He goes on to enumerate the reasons that make the mystic a socially dead being. Firstly, the mystic has an introvert temperament that makes him focused on introspection and contemplation more than on social action. Secondly, the mystic is more engaged in, attentive and attracted to, and ultimately fascinated by, the absolute Being, which also leads him to give up his social life for the benefit of this blessed quest. Thirdly, the mystic sees the human life experience as a mystery which leads him to search for the esoteric side of the religion he belongs to, which ultimately moves him away from the conventional path. By engaging in the exploration of the secrets of life, the mystic wishes to stand out from the masses. Keller states that many circumstances can lead the mystic to venture out in search of spiritual paths that are out of the ordinary. The common feature of these mystics is that they become willingly marginal in the society by being engaged in the above-mentioned matters. They form a counterculture or a counter-society.

At the same time, Al-Jabri stresses that the Sufi adepts have claimed ownership of a key ethical concept: Futuwwa. ${ }^{37}$ The concept of Futuwwa originated from the pre-Islamic era and implies a certain meaning of social responsibility. In this respect, the Sufi scholars have elaborated on this concept and claimed to be the people of Futuwwa who seek justice for others even at the expense of themselves. For them, Futuwwa is a synonym of generosity, self-sacrifice, justice-seeking and chivalry towards others. However, at the very essence of Futuwwa lays an active participation in matters that shape the society's destiny, which stands in contrast to the Sufi orders' detachment from the material political and societal issues. The Sufi orders and Sufis in general are far from being the representatives of Futuwwa as their contribution to society's freedom and civil rights militancy remain very limited. Furthermore, Sufism is responsible for the appearance or at least the promotion of counterculture or counter-society movements that weaken the meaning

${ }^{35}$ Carl-A. Keller did a comparative analysis of mysticism in Christianity, Islam, Judaism, Buddhism, and Hinduism. This allows him to formulate some generalisations about the main aspects of mysticism.

36 C.-A. Keller, Une approche de la mystique..., p. 370.

${ }^{37}$ M.A. Al-Jabri, The critique of Arab Mind..., p. 490. 
of responsibility. This is because responsibility presupposes first and foremost the acceptance of an active, positive, and proactive approach towards life.

Keller writes that these mystic counterculture orders find their origins in the Islamic middle ages, when two main mystic schools were thriving: Malamatiyya (9th century) and Qalandariyya (12th century).

The Malamati values and practices are an attempt to humiliate the nafs [self] with every action so that they may work toward a spiritual transformation. The 'path of blame' requires that an individual always acknowledges his or her blame and holds himself or herself in contempt. In this way, their inner being is directed towards a connection with God, however the interior is kept secret by an exterior that is non-conformist or unruly. ${ }^{38}$

"They live on two planes, a double life", says Morris Sigel Seale. ${ }^{39}$ The adepts of this movement would therefore engage publicly in all sorts of eccentric practices: heresy, scepticism and every non-Islamic, non-ethical and blameable behaviours in order to receive all sorts of reproach and stringent criticism from the community they interact with. While they demonstrate these dreadful practices to the outer world, they engage privately in all sorts of redemption, worship, and repentance that would bring them closer to God. By showing the ugly face to their peers and reserving their religious practices to their private sphere, they make sure that their behaviours are in no case subject to hypocrisy. Their interaction with the outer world becomes therefore negative, counterproductive, and anti-social.

The Qalandariyya was a more eccentric movement in that the practices of its adepts wholly involved alcohol, drugs, libertinism and all kinds of imaginable debauchery etc. They despised moral rules and claimed total freedom like thate one attributed to God. They believed that their religious practices and existence had a cosmic dimension and that the secrets of divinity had been disclosed to them, therefore they had freed themselves from the duties and morality, so they did not have to respect the moral law. They lived a double life: one earthly and another one cosmic, near God. Clearly, their contribution to their society proved to be irresponsible and harmful. Keller writes that similar counter-society schools still exist now under different designations: Kaksar (Iran), Majzub (India) and Heddawa (West Africa). ${ }^{40}$

Upon the outbreak of Sufism, poverty of the Sufis was a voluntary way of life. It was believed that the a Sufi should place his existence in the hands of God and put in him his absolute trust (Tawakkul). In order to fulfil his spiritual destination, he should keep his material needs to a bare minimum and disengage from any material occupation that could provide for his needs. The Sufi would rather live on charity than spend his time engaged in a social occupation.

Keller writes that "a compromise had to be found to this issue [material occupation] within the Sufi orders. The Sufi subject, henceforth, is required to provide for his basic needs of living. Begging is progressively discouraged and replaced by

\footnotetext{
38 C.-A. Keller, Une approche de la mystique..., p. 380.

${ }^{39}$ S.M. Seale, "The Ethics of Malamatiya, Sufism and the Sermon on the Mount", The Muslim World 58 [1] (1968), p. 16.

${ }^{40}$ C.-A. Keller, Une approche de la mystique..., p. 359.
} 
other solutions". ${ }^{41}$ John Renard remarks: "somewhere in the middle of that spectrum, a number of orders and Sheikhs were willing to serve as spiritual guides, teachers, and advisors to rulers and their families while seeking to maintain a measure of autonomy and freedom from reliance on the royal dole for survival. Royal patronage of Sufi institutions in the form of endowments has been a major factor in the survival and development of many major organizations". ${ }^{42}$ This change of the standpoint or a new compromise played a crucial role in making the Sufi movement viable and easily expandable and not restricted to a very negligible population.

However, one can argue that the first concern of the Sufi orders was not that their adepts climb the social ladder, or contribute to building a society and future, or fulfil personal and material objectives through work and creativity, synonymous with liberating oneself from the shackles of need; instead, the basic objective was primarily to release the Sufi orders from the burden of providing housing, food, and clothing to their members.

One can further argue that the Sufi conception of life, freedom, and responsibility described above is not harmful if it is experienced or conducted at an individual level, as it is everyone's own right to fill the spiritual void and search for the ways to one's own salvation. However, as Al-Jabri claims, once this ideology is organised in socio-religious orders that establish tyranny and obedience as primary values, the damage is condemnable, all the more so because Sufism in Arab-Islamic countries is not a marginal phenomenon. Millions of people belong to the Sufi orders which exert a profound impact on the whole Arabic community.

On the other hand, while Sufism claims, and rightly so, that, through continence and material resignation, its ideology serves as a remedy to a plethora of modern societal problems linked to consumerism, the environment, and materialism, it also consecrates the complete detachment of the self from the world, with the Sufi journey leading to - as a Sufi expression has it - 'dying before death', which means that "one should curb one's worldly requirements and selfishness and submit oneself to the will of God". ${ }^{43}$

\section{Conclusion}

Using Al-Jabri's obedience paradigm served as a way to assess the centrality of the Sufi ethical values of obedience and the annihilation of the self, and their implications for the Sufi conception of responsibility. I conclude that such values contribute to the weakening of both freedom and responsibility of the Sufi orders and their followers. In fact, these orders have shown to pose economic and political burdens on Arabic-Islamic societies. Not only do they refrain from participating in shaping the destiny of their own people, but they also submit their own will and freedom to their guides (Sheikhs). Their disinterest in the material life and political matters results

\footnotetext{
41 Ibid., p. 360.

${ }^{42}$ J. Renard, The A to $Z$ of Sufism, Plymouth 2009, p. 185.

${ }^{43}$ M.A. Qadri, What is Tasawwuf?..., p. 7.
} 
in their indifference towards the political system they are subordinate to. They are also economically far less productive and efficient. They survive on the subsidies they receive from the tyrannical State. Their attitude is indifferent. They choose to immerse themselves into an immaterial world that promises them salvation, instead of overcoming the material limitations and needs of the Arabic communities through innovation, creativity and work. They choose to accept poverty as a way to come closer to the annihilation of their selves. To summarisze, their sense of freedom is synonymous with the servitude and obedience to their guides and indirectly to the political establishment. Their sense of responsibility is that of refraining from the material life and seeking the self-annihilation in the godly Being.

As a result, if any conventional concepts of freedom and responsibility are to be defined or redefined within the Arab-Islamic tradition, they must distance themselves from the Sufi value system, for the latter does not belong to the realm of the political, cultural, and societal codes of conduct but to the mystical realm. If accepted and translated into the public sphere, Sufism is likely to do more damage than good to the very essence of these two intrinsic values. Therefore, Sufism should not be promoted in any way in the public sphere but be confined to the private one. While the spirituality and mysticism advocated by Sufism may be appreciated on an individual level, its advocacy of renouncing one's freedom and responsibility should be resisted or at least demystified through enlightened education. Finally, political bodies must refrain from intervening in the promotion of Sufi values considering that they contribute to making social and political tyranny durable.

\section{References}

Al-Jabri M.A., The critique of Arab Mind: the Arabic Ethical Mind, Beirut 2001.

Al-Masbahi M., "Freedom as servitude for In Arabi", Al Azmina Al Haditha: Philosophical Publication: The questions and stakes around Freedom 5 (2012), pp. 35-49.

Al-Suhawardi A.N.Q, Kitab Adab Al-Muridin, Jerusalem 1978.

Ben Ridouane S.A., Etude sur le Soufisme, Fenn at-Tassawwouf, transl. M.A. Arnaud, Whitefish 1888 (2010 Edition).

Corbin H., History of Islamic Philosophy, transl. L. Sherrard, Ph. Sherrard, London 1962.

Gramlich R., Die schiitischen Derwischorden Persiens. Zweiter Teil: Glaube und Lehre, Wiesbaden 1976.

Keller C.A., Une approche de la mystique dans les religions occidentales et orientales, Paris 1996.

Kubilay A., "Sufism, Spirituality and Sustainability-Rethinking Islamic Mysticism through contemporary sociology", Comparative Islamic Studies 4 [1-2] (2008), pp. 1-15, http://images.gmanews.tv/pdf/aseanconf/AKMAN\%20Kubilay.pdf (accessed: 1.02.2020).

Qadri M.A., What is Tasawwuf? An answer by Hadrat Ali bin Uthman al-Hajweri, IECRC online publication, 2003, http://www.iecrcna.org/publications articles/Tasawwuf/_Data_Ganj_Buksh.pdf (accessed: 1.02.2020). 
Renard J., The A to Z of Sufism, Plymouth 2009.

Seale S.M., "The Ethics of Malamatiya, Sufism and the Sermon on the Mount", The Muslim World 58 [1] (1968), pp. 12-23. 